\title{
EFEKTIVITAS METODE MEMOTIVASI STUDI MURID DENGAN CARA PROBLEM SOLVING KHUSUS PEMBELAJARAN MATERI ILMU FIQIH DI MADRASAH ALIYAH "MIFTAHUL ULUM" DESA NGEMBAL KECAMATAN TUTUR KABUPATEN PASURUAN KELAS XI, TAHUN PELAJARAN 2018-2019
}

\author{
M. Jamhuri \\ jamhuri@yudharta.ac.id \\ Universitas Yudharta Pasuruan
}

\begin{abstract}
Motivation is an invitation or encouragement to students by using a method or method so that students can increase the spirit of learning with their own awareness without any coercion from anyone including the teacher, so that with the motivation of the teacher students are more likely to pursue lessons than others either at home or at school.

Many parties who indicate the low quality of education today is closely related to the low motivation of students. In order to solve learning problems such efforts need to be made efforts, which include the development of learning strategies that are able to optimize student learning motivation in order to improve the quality of overall learning in learning. The formulation of the problem is How is the influence of the problem solving method (problem solving) on increasing the learning spirit of students of class XI M.A "MIFTAHULULUM" Ngembal? What are the advantages and disadvantages of problem solving methods in teaching and learning activities?

With the application of problem solving methods (problem solving) in class XI M.A MIFTAHUL ULUM Ngembal, the student's learning spirit is increasing as evidenced by the number of students who often argue in solving a problem using literature that has been read and active. The advantages of applying problem solving methods (problem solving) students can actively participate in teaching and learning activities and think more critically than before, so that the classroom atmosphere becomes more alive. Weaknesses of application to implement problem solving methods, namely the provision of reading books as supporting materials. And the time required is relatively long because students usually require time to think so that their opinions are correct and correct.
\end{abstract}

Keywords: Motivating Methods, Problem Solving, Fiqh Science. 


\section{PENDAHULUAN}

Banyak pihak yang mensinyalir rendahnya kualitas pendidikan saat ini berkaitan erat dengan rendahnya motivasi siswa Untuk memecahkan masalah pembelajaran yang demikian perlu dilakukan upaya, yang antara lain berupa pengembangan strategi pembelajaran yang mampu mengoptimalkan motivasi belajar siswa dalam rangka peningkatan kualitas pembelajaran secara menyeluruh dalam belajar.

Metode Pembelajaran Problem Solving adalah merupakan salah satu pendekatan pembelajaran motivasional yang diyakini mampu meningkatkan motivasi maupun prestasi siswa dalam belajar. Berdasarkan kenyataan diatas maka kami melakukan Penelitian Tindakan Kelas dengan judul "Metode Memotivasi Studi Murid dengan Cara Problem Solving Husus Pembelajaran Materi Ilmu Fiqih di Madrasah Aliyah "Miftahul Ulum" Desa Ngembal Kecamatan Tutur Kabupaten Pasuruan Kelas Xi, Tahun Pelajaran 2018-2019". Pada penelitian ini akan dikembangkan metode serta tindakantindakan yang dapat meningkatkan motivasi belajar siswa Madrasah Aliyah Miftahul Ulum Ngembal Tutur Pasuruan.

\section{KAJIAN TEORI}

\section{Pengertian Metode Problem Solving}

Metode ini berasal dari John Dewey, maksud utama metode ini adalah memberikan latihan kepada siswa dalam berpikir. Metode ini dapat menghindarkan dalam pembuatan kesimpulan yang tergesagesa. Proses menimbang-nimbang berbagai kemungkinan pemecahan dan menangguhkan pengambilan keputusan sampai terdapat bukti-bukti yang cukup akan menjadi dasar dalam penerapan metode ini.

Metode problem solving (pemecahan masalah) atau suatu metode dalam pendidikan dan pengajaran dengan sejalan melatih anak-anak (siswa) untiik menghadapi masalah-masalah dari yang paling sederhana sampai kepada masalah yang paling rumit. Metode ini biasanya dikombinasikan dengan metode proyek, dimana anak dihadapkan pada masalah-masalah, kemudian disuruh memecahkan sendiri sampai mendapatkan pemecahannya atau kesimpulannya. ${ }^{1}$

Suatu masalah yang akan dipecahkan selalu mempunyai ciri yaitu adanya suatu kesulitan baik yang bersifat psikis maupun fisik.maksudnya

\footnotetext{
${ }^{1}$ Zuhairini, dkk, Metodik Khusus Pendidikan Agama, Usaha Nasional, Surabaya, 1997. 110.
} 
dalam percakapan sehari-hari dikatakan bahwa ada persoalan yang memerlukan otak dan ada yang memerlukan otot untuk dapat memecahkannya. Oleh sebab itulah maka sebaiknya suatu masalah yang akan dipecahkan oleh murid harus selalu merupakan masalah yang kepentingan pemecahannya benar-benar dihayati sebagai kebutuhan bagi hidupnya.

Suatu masalah dikatakan masalah yang baik bila memenuhi syaratsyatar sebagai berikut:

a. Jelas, dalam arti bersih dari kesalahan-kesalahan bahasa maupun isi pengertian yang berbeda.

1. Kesulitan dapat diatasi, maksudnya adalah bahwa pokok persoalan yang akan dipecahkan tidak merupakan pokok berganda

2. Bernilai bagi murid, hasil atupun proses yang dialami murid harus bermanfaat dan menguntungkan pengalaman murid atau memperkaya pengalaman murid.

3. Sesuai dengan perkembanganm psikis murid, masalah yang dipecahkan tidak terlalu mudah dan tidak terlalu sulit.

4. Praktis, dalam artian mungkin dijumpai delam kehidupan seharihari. $^{2}$

Adapun tujuan utama dari penggunaan metode problem solving dalam kegiatan belajar mengajar adalah sebagai berikut:

1. mengembangkan kemampuan berpikir, terutama dalam mencari sebab akibat dan tujuan dari suatu permasalahan.

2. memberikan kepada siswa pengetahuan dan kecakapan praktis yang bernilai atau bermanfaat bagi keperluan hidup sehari-hari.

3. belajar bagaimana dalam bertindak dalam suatu situasi baru.

4. belajar bekerja secara sistematis diwaktu memecahkan suatu permasalahan.

Metode problem solving (pemecahan masalah) tepat digunakan:

1. apabila pelajaran dimaksudkan untuk melatih siswa untuk berpikir kritis dan analitis.

2. apabila pelajaran dimaksudkan untuk melatih siswa memiliki keberanian dan rasa tanggung jawab dalam mengahadapi masalah-masalah kehidupan kelak dimasyarakat.

\section{Pengertian Pembelajaran.}

\footnotetext{
${ }^{2}$ Roestiyah, dkk, Didaktik Metodik, PT Bina Aksara, Jakarta, 1986. 80 
M. Basyiruddin Usman dalam bukunya "Metodologi pembelajaran Agama Islam”, mengatakan bahwa:

"Proses belajar mengajar menurut Para ahli pendidikan berbeda pendapat dalam merumuskan defenisi pengajaran yang disebabkan oleh adanya perbedaan dalam mengidentifikasi data, menafsirkan data, penggunaan terminologi dan konotasi istilah penekanan terhadap aspek tertentu. Disamping faktor-faktor tersebut pembelajaran adalah suatu yang kompleks yang tidak hanya sekedar menyampaikan informasi oleh pengajar kepada pembelajar, tetapi banyak kegiatan yang harus dilakukan dan dipertimbangkan, oleh karena itu rumusan pengertian pembelajaran tidak sederhana yang dibayangkan".

S. Nasution, dalam M. Basyiruddin Usman,2002, merumuskan pengertian mengajar sebagai berikut :

a. Pembelajaran ialah menanamkan pengetahuan pada peserta didik.

b. Pembelajaran ialah menyampaikan kebudayaan kepada peserta didik.

c. Pembelajaran ialah aktifitas mengorganisasi atau mengatur lingkungan dengan sebaik-baiknya serta menghubungkan dengan pelajar sehingga menjadi proses belajar-mengajar. ${ }^{3}$

Definisi pembelajaran yang dikemukakan diatas tersebut mengandung pemahaman sebagai berikut:

Definisi pertama: pembelajaran bertujuan agar anak didik dapat menguasai pengetahuan yang diberikan oleh pengajar, dimana peserta didik hanya bersifat pasif sedang pengajar bersifat aktif mengajar yang lazim disebut "Teacher Centered".

Definisi kedua: sama dengan definisi pertama, dimaksudkan agar peserta didik dapat mengenal kebudayaan bangsa dan kebudayaan dunia, bahkan agar peserta didik tidak hanya sekedar mengenal kebudayaan tetapi turut serta menciptakan kebudayaan yang baru sesuai dengan tuntutan zaman yang selalu berubah.

Definisi ketiga: berbeda dengan definisi pertama dan kedua, yakni suatu usaha pengajar untuk mengatur dan mengorganisir lingkungan sehingga dapat tercipta situasi dan kondisi yang baik bagi peserta belajar. Dengan demikian peserta belajar dapat belajar secara aktif dan pengajar berperan sebagai pembimbing dan mengorganisasi terhadap kondisi belajar peserta belajar.

${ }^{3}$ Roestiyah, dkk, Didaktik Metodik, PT Bina Aksara, Jakarta, 1986. 99. 
Hasibuan dan Moedjiono, dalam M. Basyiruddin Usman, memberikan definisi Pembelajaran adalah:

"Penciptaan situasi lingkungan yang memungkinkan terjadinya proses belajar. Sistem lingkungan tersebut terdiri dari komponenkomponen yang saling mempengaruhi, antara lain: tujuan, Pengajar, pembelajar, materi, jenis kegiatan yang dilakukan, sarana dan prasarana belajar mengajar yang tersedia".

Pengertian Pengajaran yang dikemukakan oleh Hasibuan tersebut mengandung makna Pembelajaran, sama halnya dengan yang dikemukakan oleh S. Nasution pada definisi ketiga yang pada intinya"mengatur lingkungan agar peserta belajar benar-benar merasakan situasi yang kondusip saat belajar". 4

Terjadinya proses tingkah laku disebabkan oleh adanya interaksi antara peserta didik dengan lingkungan. Oleh karena itu perubahan tingkah laku seseorang dapat terjadi karena dua hal yakni :

a. Faktor intern, yaitu faktor dimensi dalam menerima perubahan.

b. Faktor ekstern, yaitu lingkungan yang dapat merangsang, menunjang dan memperlancar proses belajar.

Jadi dapat disimpulkan pengajaran adalah suatu usaha bagaimana mengatur lingkungan dan adanya interaksi peserta belajar dengan lingkungan sehingga tercipta kondisi belajar yang baik.

Bila pengertian pembelajaran ditujukan untuk penguasaan bahan pelajaran semata, akan memberi makna yang terlalu sempit dan bersifat intelektualistis, para ahli berpendapat bahwa belajar bukan sekedar penguasaan bahan akan tetapi terjadinya perubahan tingkah laku anak sehingga terbentuk suatu kepribadian yang baik. ${ }^{5}$

Sikun Pribadi, Guru besar IKIP Bandung pada "mimbar pendidikan 1974", dalam Ahmad Tafsir,1995, Pernah menjelaskan masalah ini dalam salah satu tulisannya. Menurutnya Pendidikan dalam arti Pedagogis tidak dapat disamakan dengan pengertian Pembelajaran, Pembelajaran menurut pendapatnya ialah: Suatu kegiatan yang menyangkut Pembinaan peserta didik mengenai segi kognitif, Psikomotorik semata, supaya peserta didik lebih banyak pengetahuan, lebih cakap berfikir kritis, sistematis dan obyektif serta terampil dalam

\footnotetext{
${ }^{4}$ Zuhairini, dkk, Metodik Khusus Pendidikan Agama, Usaha Nasional, Surabaya, 1997. 120

${ }^{5}$ Roestiyah, dkk, Didaktik Metodik, PT Bina Aksara, Jakarta, 1986.110
} 
mengerjakan sesuatu. Misalnya: terampil menulis, membaca, lari cepat, loncat tinggi, berenang, membuat pesawat radio dan sebagainya. Tujuan pengajaran lebih mudah ditentukan dari pada tujuan pendidikan, karena tujuan pendidikan adalah menyangkut seluruh kepribadian peserta didik termasuk akhlaq tingkah laku sehari-hari (affektif), yang lebih sukar ditentukan. Sementara Kihajar Dewantara mengatakan bahwa pembelajaran itu adalah sebagian dari pendidikan, dengan kata lain bahwa: pengajaran ialah Proses pemindahan ide dengan cara memberikan ilmu atau pengetahuan serta kecakapan.

Jadi tidak terdapat perbedaan mendasar antara pendapat sikun pribadi Guru Besar IKIP Bandung dan pendapat Kihajar Dewantara diatas. Menurut keduanya Pendidkan ialah: melaksanakan berbagai usaha untuk menolong peserta didik dalam menuju kedewasaannya, salah satu diantara sekian banyak usaha yang dapat dilakukan adalah dengan cara pembelajaran. Usaha lain semacam memberikan contoh yang tingkah laku yang baik (Uswatun Hasanah), pembiasaan memberikan hadiah, pujian, hukuman, larangan dan sebagainya. Sekalipun pengertian pendidikan dan pembelajaran yang diberikan oleh Sikun pribadi Guru Besar IKIP Bandung, dan Kihajar Dewantara tersebut diatas, hanya berlaku bagi pendidikan yang melibatkan Pendidik, namun pengertian itu dapat dipakai sekurang-kurangnya untuk pengertian pendidikan dalam arti sempit. ${ }^{6}$

\section{Pengertian Pendidikan Agama Islam.}

Menurut Ali Maksum dalam bukunya "Pluralisme dan Multikulturalisme Paradigma baru Pendidikan agama Islam Di Indonesia" mendefinisikan Pendidikan agama Islam adalah: suatu proses yang berlangsung secara kontinu dan berkesinambungan. Dalam hal ini tugas dan fungsi yang di emban pendidikan Islam adalah pendidikan manusia seutuhnya dan dijalankan sepanjang hayat (Long life Education). ${ }^{7}$

\footnotetext{
${ }^{6}$ Roestiyah, dkk, Didaktik Metodik, PT Bina Aksara, Jakarta, 1986. 130.

${ }^{7}$ Ibid., 133.
} 
Sedang pendidikan Islam menurut ahmad D. Marimba dalam Bukunya "Pengantar Filsafat Pendidikan" 1989, adalah bimbingan jasmani maupun rohani berdasarkan hukum-hukum agama". 8

Menurut H. Susari dalam bukunya "Pendidikan agama Islam dalam Prespektif Multikulturalisme" mengatakan bahwa:

Istilah pendidikan Islam dalam Persepektif pendidikan Islam Pada Umumnya mengacu pada tiga term dalam bahasa arab yaitu: alTarbiyah, al-Ta'lim dan al-Ta'dib, ketiga trem tersebut meskipun mempunyai maksud yang sama untuk mendefinisikan tentang pendidikan dalam Islam, namaun ketiganya mempunyai perbedaan, baik tekstual maupun kontekstual". 9

Dalam kitab "al-Ma'luf, al-Munjid filloghoh wal-alam" dalam H.Susari:

a. Al-Tarbiyah: berasal dari kata "Rabba" yang artinya bertambah atau mengambil sesuatu yang lebih banyak dari yang diberikan dan tumbuh-tumbuh.

Dalam kamus al-Munawir dalam Omar Muhammad al-Taumy al-Syibani, dalam H.Susari:

al-Tarbiyah berarti Pendidikan, Pengasuhan dan Pemeliharaan, dalam surat al-Fatihah ayat 1 dan 2 " Alhamdu Lillahi Rabb al-Alamin" mempunyai kandungan ma'na yang berkonotasi dengan term al-Tarbiyah yang akar katanya Rabba, dalam ayat tersebut menggambarkan adanya keterkaitan antara tuhan dan kegiatan Pendidikan, artinya Alloh adalah Pendidik yang maha agung dialam raya ini bukan saja Pendidik bagi manusia saja akan tetapi bagi sekian makhluk dialam semista.

b. Al-Ta'lim: merupakan bentuk masdar dari 'allama yang artinya mengajar. Dalam perspektif ilmu pendidikan, mengajar lebih menekankan pada dimensi kognitif. afektif dan psikomotorik, jadi tiga domain yaitu kognitif, afektif dan psikomotorik ini yang sangat terlibat dalam kata al-Ta'lim diatas.

c. Al-Ta'dib: adalah penanaman $a d a b$ dalam diri manusia, adab sendiri mengandung pengertian tentang apa yang harus ditanamkan dalam diri seseorang, jika ia ingin memperoleh kesoksesan dalam hidupnya

\footnotetext{
${ }^{8}$ Muhaimin, dkk, Strategi Belajar Mengajar: Penerapannya Dalam Pembelajaran Pendidikan Agama, CV. Citra Media, Surabaya, 1996. 143.

${ }^{9}$ Zuhairini, dkk, Metodik Khusus Pendidikan Agama, Usaha Nasional, Surabaya, 1997. 130
} 
baik didunia maupun di akhirat. Adab adalah disiplin badan, pemikiran dan jiwa, yang menjamin seorang pada pengakuan dan penghargaan yang layak terkait dengan potensi dan kapasitas fisik,intelektual dan spiritualnya yang bisa mengantarkan pada diri manusia akan tujuan pendidikan yaitu menambah kebijakan pada diri manusia, secara personal dan indifidual. Konsep kebijakan manusia meliputi dimensi material dan spiritual, konsep ini lebih tepat menggunakan istilah adab/ta'dib. Jadi pendidikan agama Islam setidaknya harus mencakup pengertian yang terkandung dari istilah al-Tarbiyah, al-Ta'lim dan al-Ta'dib. Yaitu suatu kegiatan menumbuhkan dan mengembangkan potensi dan kapasitas fisik, intlektual, dan spiritual peserta didik agar memperoleh kebajikan, baik secara material maupun sepiritual. Pendidikan tidak hanya sekedar terhenti pada aspek rasio (intelektual), tetapi jugaaspek lain untuk melihat potensi manusia secara utuh, berkepribadian, moral, dan sepiritual.

Menurut Zakiyah Daradjat:

"Pendidikan agama Islam adalah pendidikan individual dan masyarakat yang mana didalam ajaran Islam berisi tentang sikap dan tingkah laku pribadi masyarakat menuju kesejahteraan hidup perorangan dan bersama serta lebih banyak menekankan pada perbaikan sikap mental yang akan terwujud dalam amal perbuatan,baik untuk keperluan sendiri maupun bagi orang lain.

Menurut Zuhairini dalam bukunya "Filsafat Pendidikan Islam" Pendidikan agama Islam adalah:

"Pemberi corak hitam putihnya perjalanan hidup seseorang, oleh karena itu ajaran Islam menetapkan bahwa pendidikan merupakan salah satu kegiatan yang wajib hukumnya bagi peria dan wanita dan berlangsung seumur hidup semenjak dari buaian, hingga ajal tiba".

Pendidikan menurut Lodge dalam Zuhairini: Bahwa seluruh Proses hidup dan kehidupan manusia itu adalah proses pendidikan, segala pengalaman sepanjang hidupnya merupakan dan memberikan pengaruh pendidikan baginya. ${ }^{10}$

10 Muhaimin, dkk, Strategi Belajar Mengajar: Penerapannya Dalam Pembelajaran Pendidikan Agama, CV. Citra Media, Surabaya, 1996. 200. 
Dalam Peraturan Menteri Pendidikan Nasional Nomor 20 Tahun 2003 Bab I (Pasal 1) Pendidikan agama adalah:

"pendidikan yang memberikan pengetahuan dan membentuk sikap, kepribadian, dan keterampilan peserta didik dalam mengamalkan ajaran agamanya, yang dilaksanakan sekurang-kurangnya melalui mata pelajaran/kuliah pada semua jalur, jenjang dan jenis pendidikan”.

Pengertian agama secara sederhana dari sudut pandang kebahasaan (etimologi) bahasa indonesia diambil dari kata yang berasal dari bahasa sansekerta yang A berarti "tidak", gama berarti "kacau",jadi 'agama' berarti 'tidak kacau'. Hal ini mengandung pengertian bahwa: "Agama adalah suatu peraturan yang mengatur kehidupan manusia agar tidak kacau dalam kehidupannya". ${ }^{11}$

\section{Paradigma Pembelajaran Pendidikan Agama Islam}

Agama Islam adalah agama yang universal, yang mengajarkan kepada ummat manusia mengenai berbagai aspek kehidupan, baik duniawi maupun ukhrowi. Salah satu diantara ajaran Islam tersebur adalah mewajibkan kepada ummat Islam untuk melaksanakan pendidikan, karena menurut ajaran Islam pendidikan adalah juga merupakan kebutuhan hidup manusia yang mutlak harus dipenuhidemi mencapai kesejahteraan dan kebahagiaan dunia dan akhirat, dengan Pendidikan itu pula manusia akan mendapatkan berbagai ilmu pengetahuan untuk bekal kehidupannya. Apabila kita perhatikan ayat-ayat yang diturunkan pertama kali oleh Alloh kepada Nabi Muhammad,maka nyatalah bahwa Alloh telah menekankan perlunya orang menekuni pembelajaran dan pendidikan agama Islam.

\section{Rencana Tindakan}

\section{a. Kegiatan Peneliti:}

1. Peneliti menetapkan suatu pokok atau problema yang akan dipecahkan guru meminta kepada siswa untuk mengemukakan suatu pokok permasalahan.

2. Guru mengatur giliran pembicaraan agar semua siswa tidak serempak berbicara mengemukakan pendapatnya masing-masing.

3. Menjaga suasana kelas dan mengatur setiap pembicara agar

${ }^{11}$ Ibid., 210. 
seluruh kelas dapat mendapatkan apa yang sedang dikemukakan.

4. Mengatur agar sifat atau isi pembicaraan tidak menyimpang dari pokok permasalahan.

\section{b. Kegiatan siswa}

1. Menelaah topik atau pokok permasalahan yang diajukan guru, atau mengusulkan suatu problema.

2. Ikut aktif memikirkan sendiri atau mencari sumber atau data dari buku-buku sumber pengetahuan lain agar dapat menemukan jawaban pemecahan masalah yang diajukan.

3. Menghormati pendapat teman-temannya walaupun tidak setuju dengan pendapat yang dikemukakan.

\section{HASIL PENELITIAN}

\section{Siklus Pertama}

a. Perencanaan

1) Peneliti menetapkan suatu pokok atau problema yang akan dipecahkan guru meminta kepada siswa untuk mengemukakan suatu pokok permasalahan

2) Guru mengatur giliran pembicaraan agar semua siswa tidak serempak berbicara mengemukakan pendapatnya masing-masing

3) Menjaga suasana kelas dan mengatur setiap pembicara agar seluruh kelas dapat mendapatkan apa yang sedang dikemukakan

4) Mengatur agar sifat atau isi pembicaraan tidak menyimpang dari pokok permasalahan

b. Pelaksanaan

1) Tahap awal:

- membuka pelajaran

- perkenalan antara peneliti dan siswa

2) Tahap inti:

- memberikan penjelasan mengenai maksud dan tujuan penelitian di M.A MIFTAHUL ULUM Ngembal Tutur pasuruan

- membantu siswa menyiapkan bahan atau media yang diperlukan dalam penelitian ilmiah

- peneliti memberikan rangsangan berfikir pada siswa bagaimana cara berpartisipasi dalam penelitian ini

- memberikan Topik Permasalahan

- memberi kesempatan pada siswa untuk berpendapat dan 
berdiskusi sesuai dengan tema

3) Tahap akhir

- peneliti menyimpulkan hasil diskusi dan memberikan pemantapan

- peneliti memberikan himbauan dan motivasi kepada siswa untuk membaca buku-buku yang berkaitan dengan materi yang akan dibahas.

- peneliti menutup pelajaran

c. Pengamatan

Penelitian tindakan kelas yang dilakukan di Madrasah Aliyah MIFTAHUL ULUM kelas XI ini menerapkan metode problem solving (pemecahan masalah) dalam kegiatan belajar mengajar dan didapat hasil yang cukup memuaskan.

Dari pengamatan dapat diketahui secara langsung bahwa dengan metode tersebut suasana kelas menjadi hidup. Hal ini dibuktikan dengan banyaknya siswa yang ikut aktif dalam mengajukan permasalahan dan memecahkan suatu permasalahan. Dalam memecahkan berbagai permasalahan, siswa seringkali menggunakan buku rujukan yang ada kaitannya dengan permasalahan dan juga disertai dengan alasan-alasan yang rasional. Disamping itu pula banyak siswa yang terlihat antusias dalam mendengarkan permasalahan dan pemecahannya, sehingga terlihat tidak ada siswa yang mengantuk, main-main, bergurau dan bahkan tertidur.

d. Refleksi

Sesuai dengan apa yang telah kami amati, penggunaan metode problem solving dalam pelajaran Fiqih kelas XI melalui perencanaan tindakan yang telah dibuat sebelumnya, maka dapat diambil suatu kesimpulan bahwa metode tersebut telah memberikan hasil yang maksimal. ini terbukti dengan bersemangatya siswa dalam proses kegiatan belajar mengajar dikelas sehingga suasana kelas menjadi hidup. Walaupun demikian perlu adanya suatu pembenahan guna mencapai hasil yang maksimal dalam penerapan metode ini. Langkah berikutnya kami akan merencanakan dan menguji kembali penerapan metode ini dalam siklus ke dua. 


\section{Siklus kedua:}

a. Perencanaan

1) Peneliti menetapkan suatu pokok atau problema yang akan dipecahkan guru meminta kepada siswa untuk mengemukakan suatu pokok permasalahan

2) Guru mengatur giliran pembicaraan agar semua siswa tidak serempak berbicara mengemukakan pendapatnya masing-masing

3) Menjaga suasana kelas dan mengatur setiap pembicara agar seluruh kelas dapat mendapatkan apa yang sedang dikemukakan

4) Mengatur agar sifat atau isi pembicaraan tidak menyimpang dari pokok permasalahan

\section{b. Pelaksanaan}

1) Tahap awal:

- membuka pelajaran

- pemberian motivasi dan review

2) Tahap inti:

- membantu siswa menyiapkan bahan atau media yang diperlukan dalam penelitian ilmiah

- peneliti memberikan rangsangan berfikir

- peneliti mempersilahkan siswa untuk melanjutkan diskusi kemarin

- memberi kesempatan pada siswa untuk berpendapat dan berdiskusi sesuai dengan tema peneliti

- peneliti memberi pertanyaan kepada siswa

3) Tahap akhir

- peneliti menyimpulkan hasil diskusi dan memberikan pemantapan

- peneliti memberikan himbauan dan motivasi kepada siswa untuk membaca buku-buku yang berkaitan dengan materi yang akan dibahas.

- peneliti menutup pelajaran

\section{c. Pengamatan.}

Dari pengamatan juga dapat diketahui secara langsung bahwa dengan metode tersebut suasana kelas menjadi hidup. Hal ini juga dibuktikan dengan banyaknya siswa yang ikut aktif dalam mengajukan permasalahan dan memecahkan suatu permasalahan. Dalam memecahkan berbagai permasalahan, siswa juga seringkali 
menggunakan buku rujukan yang ada kaitannya dengan permasalahan dan juga disertai dengan alasan-alasan yang rasional.

\section{d. Refleksi}

Sesuai dengan apa yang telah kami amati, penggunaan metode problem solving dalam pelajaran Fiqih M.A Miftahul Ulum Ngembal kelas XI pada siklus kedua ini, maka dapat pula diambil suatu kesimpulan bahwa metode tersebut telah memberikan hasil yang maksimal. ini terbukti dengan bersemangatya siswa dalam proses kegiatan belajar mengajar dikelas sehingga suasana kelas menjadi hidup. Penelitian kedua ini juga didasarkan melalui perencanaan tindakan yang telah dibuat sebelumnya. Untuk lebih memantapkan keefektifan penggunaan metode ini dalam proses belajar mengajar, kami akan menguji kembali pada siklus ketiga dalam Penelitian Tindakan Kelas ini.

\section{Siklus Ketiga:}

\section{a. Perencanaan}

1) Peneliti menetapkan suatu pokok atau problema yang akan dipecahkan guru meminta kepada siswa untuk mengemukakan suatu pokok permasalahan

2) Guru mengatur giliran pembicaraan agar semua siswa tidak serempak berbicara mengemukakan pendapatnya masing-masing

3) Menjaga suasana kelas dan mengatur setiap pembicara agar seluruh kelas dapat mendapatkan apa yang sedang dikemukakan

4) Mengatur agar sifat atau isi pembicaraan tidak menyimpang dari pokok permasalahan

\section{b. Pelaksanaan}

1) Tahap awal:

- membuka pelajaran

- pemberian motivasi dan review

2) Tahap inti:

- membantu siswa menyiapkan bahan atau media yang diperlukan dalam penelitian ilmiah (pemutaran CD)

- mengawasi siswa melakukan penyelidikan ilmiah

- mempersilahkan siswa memecahkan masalah dengan tema yang ada

- memberi kesempatan pada siswa untuk berpendapat dan 
berdiskusi sesuai dengan tema

3) Tahap akhir

- memberikan pemantapan, meluruskan hal-hal yang kurang tepat dan menyimpulkan

- evaluasi akhir

- Peneliti menutup pelajaran

\section{c. Pengamatan.}

Pelaksanaan metode problem solving (pemecahan masalah) di kelas XI M.A Miftahul Ulum Ngembal terlihat memperoleh basil yang sangat memuaskan. Para siswa bila dilihat sebelum diterapkan metode problem solving (pemecahan masalah) ini terlihat begitu kurang bersemangat, tidak siap dalam menerima materi pelajaran, ada yang main-main, tidur-tiduran, mengantuk, dan lain sebagainya. Begitu materi pelajaran disampaikan melalui metode problem solving (pemecahan masalah), maka siswa banyak yang antusias, bersemangat daan aktif dalaam memberikan kontribusi keilmuan (memecahkan suatu permasalahan), sehingga suasana dalam kelas terlihat lebih hidup

.Hal lain yang menjadi indikator keberhasilan metode problem solving (pemecahan masalah) ini adalah siswa kelas XI M.A MIFTAHUL ULUM Ngembal lebih sering membaca buku-buku bacaan yang dapat menunjang terhadap materi pelajaran biologi di sekolah, buku-buku ilmiah dan lain sebagainya. Untuk data hasil dari penelitian dapat dilihat pada lampiran.

\section{d. Refleksi}

Sesuai dengan apa yang telah kami amati, penggunaan metode problem solving dalam pelajaran Fiqih kelas XI melalui perencanaan tindakan yang telah dibuat sebelumnya, maka dapat diambil suatu kesimpulan bahwa metode tersebut telah memberikan hasil yang maksimal. ini terbukti dengan bersemangatnya siswa dalam proses kegiatan belajar mengajar dikelas sehingga suasana kelas menjadi hidup.

Walaupun demikian dalam metode ini terdapat beberapa kelemahan-kelemahan sehingga perlu adanya suatu pembenahan guna mencapai hasil yang maksimal dalam penerapan metode ini. Pembenahan (Refleksi) tersebut adalah: 
1) Seorang Guru jangan hanya terpaku dengan metode problem solving ini, guru juga perlu menggunakan metode-metode lainnya yang dapat menunjang terhadap pencapaian berbagai tujuan, guru juga harus memberikan rangkuman pelajaran karena siswa mudah lupa apabila materi-materi tidak dicatat..

2) Guru harus memberikan reward (penghargaan) bagi siswa yang selialu agresif dalam memecahkan berbagai permasalahan dan memberikan remedial bagi siswa yang tertinggal.

3) Guru hendaknya jangan terlalu sering memaksakan pendapatnya terhadap permasalahan yang diajukan siswa, guru hanya memberikan stimulus agar siswa dapat dengan mudah memecahkan berbagai masalah dan tercipta pendidikan yang demokratis.

\section{KESIMPULAN}

Dengan penerapan metode problem solving (pemecahan masalah) di kelas XI M.A MIFTAHUL ULUM Ngembal, maka semangat belajar siswa semakin bertambah yang dibuktikan dengan banyaknya siswa yang sering berargumen dalam memecahkan suatu permasalahan dengan menggunakan literature yang telah dibaca serta aktif.

Adapun kelebihan penerapan metode problem solving (pemecahan masalah) siswa dapat ikut aktif dalam kegiatan belajar mengajar dan lebih berpikir kritis dari pada sebelumnya, sehingga suasana kelas menjadi lebih hidup.

Kelemahan penerapan untuk melaksanakan metode problem solving yaitu penyediaan buku-buku bacaan sebagai bahan penunjang.dan waktu yang dibutuhkan relatif lama karena biasanya siswa menuntut waktu untuk berfikir agar pendapat mereka benar dan tepat.

\section{DAFTAR PUSTAKA}

Dinas Pendidikan dan Kebudayaan Jatim, Panduan Workshop Penelitian Tindakan Kelas, Tim Perluasan dan Peningkatan Baku Mutu SMU, Surabaya, 2006.

Djajadisastra, Jusuf, Metode-Metode Mengajar, Angkasa, Bandung, 1981. Muhaimin, dkk, Strategi Belajar Mengajar: Penerapannya Dalam Pembelajaran Pendidikan Agama, CV. Citra Media, Surabaya, 1996. Roestiyah, dkk, Didaktik Metodik, PT Bina Aksara, Jakarta, 1986 
216 ][ Efektivitas Metode Memotivasi Studi Murid dengan Cara Problem Solving

Zuhairini, dkk, Metodik Khusus Pendidikan Agama, Usaha Nasional, Surabaya, 1997.

Nurnal al-Murabli, Volume 4 Namar 2, Jumi 2019 